УДК 002.2-053.67:316.7

Анісімова Ольга Миколаӥвна, доктор економічних наук, професор, завідувач кафедри інформаційних систем управління Донецького національного університету ім. Василя Стуса anisimova.o.m@gmail.com orcid.org/0000-0002-8016-9361

Крисько Наталія Миколаївна, магістр,

Донецький національний університет ім. Василя Стуса kriskonat01@gmail.com orcid.org/0000-0001-8734-0080

\title{
СУЧАСНА УКРАЇНСЬКА КНИГА В ЖИТТІ МОЛОДІ ЧЕРЕЗ ПРИЗМУ СОЦІОЛОГІЧНОГО ДОСЛІДЖЕННЯ
}

Мета роботи. Дослідити рівень популярності сучасної української книги та визначити пріоритети молоді серед сучасних украӥнських письменників задля покращення укомплектованості бібліотечного фонду ВОУНБ імені К. А. Тімірязєва цією літературою. В умовах розбудови незалежної української держави важливим чинником діяльності бібліотечних закладів $\epsilon$ максимальне задоволення потреб читачів як у змістовному, так і в мовному аспекті. Необхідність вивчення цієї проблеми посідає важливе місие серед завдань кожної бібліотеки, отже враховуючи ці аспекти, тему роботи можна вважати актуальною. Методологія. У процесі дослідження застосовано наукові методи аналізу, синтезу, узагальнення, соиіологічні методи анкетування, аналітичні методи аналізу даних. Наукова новизна роботи полягає в дослідженні та аналізі рівня поінформованості молоді в галузі сучасної украӥнської літератури, визначенні жанрових вподобань молоді, дослідженні мотивів, які спонукають молодь до читання сучасної украӥнської літератури та визначенні найбільи комфортного формату читання серед користувачів ВОУНБ імені К. А. Тімірязєва. Висновки. Результати дослідження допомогли з'ясувати рівень популярності сучасної украӥнської книги серед молодих людей, визначити пріоритети молоді серед сучасних українських письменників. Враховуючи сферу бібліотечного спілкування, вдосконалення його якості бібліотека зможе підвищити свій соціальний престиж, створити зручну, затишну робочу атмосферу для реальних і потенційних читачів. Дослідження показало, щуо вищим є рівень освіти респондентів, то частіше вони читають книжки. Жінки читають друковані книжки частіше, ніж чоловіки. Найпопулярнішим серед молодих читачів жанром є психологічна література (15\%), трилери (2\%) є найменш популярним жанром серед опитаних. Результати дослідження показали мотиви, які спонукають молодь до читання сучасної украӥнської літератури. Більшість 159 (53\%) респондентів вважають, щчо ие один із важливих засобів самовдосконалення та розвитку, щьо дозволяє їм здійснити самоутвердження в усіх сферах життєдіяльності.

Ключові слова: сочіологічне опитування, література, книга, сучасна украӥнська література, інформачія. 
Анисимова Ольга Николаевна,

доктор экономических наук, профессор, заведующая кафедрой информационных систем управления Донецкого национального университета им. Василия Стуса

Крысько Наталья Николаевна, магистр,

Донецкий национальный университет им. Василия Стуса

\section{СОВРЕМЕННАЯ УКРАИНСКАЯ КНИГА В ЖИЗНИ МОЛОДЕЖИ ЧЕРЕЗ ПРИЗМУ СОЦИОЛОГИЧЕСКОГО ИССЛЕДОВАНИЯ}

Цель работы. Исследовать уровень популярности современной украинской книги и определить приоритеты молодежи среди современных украинских писателей для улучшения укомплектованности библиотечного фонда ВОУНБ имени К. А. Тимирязева этой литературой. В условиях развития независимого украинского государства важным фактором деятельности библиотечных учреждений является максимальное удовлетворение потребностей читателей как в содержательном, так и в языковом аспекте. Необходимость изучения этой проблемы занимает важное место среди задач каждой библиотеки, следовательно учитывая эти аспекты, тему работы можно считать актуальной. Методология. В процессе исследования использовалист научные методы анализа, синтеза, обобщения, сочиологические методы анкетирования, аналитические методы анализа данных. Научная новизна работы заключается в исследовании и анализе уровня осведомленности молодежи в области современной украинской литературы, определении жанровых предпочтений молодежи, исследовании мотивов, побуждаюших молодежь к чтению современной украинской литературы и определении наиболее комфортного формата чтения среди пользователей ВОУНБ имени К. А. Тимирязева. Выводы. Результаты исследования помогли выяснить уровень популярности современной украинской книги среди молодых людей, определить приоритеты молодежси среди современных украинских писателей. Учитывая сферу библиотечного общения, совершенствования его качества библиотека сможет повысить свой сочиальный престиж, создать удобную, уютную рабочую атмосферу для реальных и потенциальных читателей. Исследование показало, что выше уровень образования респондентов, тем чаще они читают книги. Женщины читают печатные книги чаще, чем мужчины. Самым популярным среди молодых читателей жанром является психологическая литература (15\%), триллеры (2\%) является наименее популярным жанром среди опрошенных. Результаты исследования показали мотивы, побуждающие молодежь к чтению современной украинской литературы. Большинство 159 (53\%) респондентов считают, что это один из важных средств самосовершенствования и развития, что позволяет им осуществить самоутверждения во всех сферах жизнедеятельности.

Ключевые слова: сочиологический опрос, литература, книга, современная украинская литература, информаиия.

Anisimova Olha, Doctor of Economics, Professor, Head of the Department of Information Systems Management, Vasyl`Stus Donetsk National University

Krysko Natalia, Master's degree,

Vasyl`Stus Donetsk National University

\section{MODERN UKRAINIAN BOOK IN YOUTH'S LIVES THROUGH THE SOCIOLOGICAL RESEARCH}

The purpose of the article is to analyze the level of popularity of the contemporary Ukrainian book and to identify the priorities of young people among contemporary Ukrainian writers to improve the completeness of the K. A. Timiryazev Vinnytsia regional universal scientific library. In the conditions of building an independent 
Ukrainian state, an essential factor in the activity of library institutions is the maximum satisfaction of the needs of readers both in content and in the linguistic aspect. The need to study this problem is an integral part of the tasks of each library, so considering these aspects, the topic of the work can be regarded as relevant. Methodology. In the course of the scientific research methods of analysis, synthesis, generalization, sociological methods of questioning, analytical methods of data analysis were applied. The scientific novelty of the article is to research and analyze the level of youth awareness in the field of contemporary Ukrainian literature, to determine the genre preferences of young people, to study the motives that prompt young people to read contemporary Ukrainian literature and to determine the most comfortable reading format among $K$. $A$. Timiryazev Vinnytsia regional universal scientific library students. Conclusions. The results of the study helped to determine the level of popularity of contemporary Ukrainian books among young people, to identify the priorities of young people among contemporary Ukrainian writers. Given the scope of library communication, improving its quality, the library will be able to enhance its social prestige, create a comfortable, cozy, working atmosphere for real and potential readers. The survey showed that the higher the education level of respondents, the more often they read books. Women read printed books more often than men. The most popular among young readers is the psychological literature (15\%), thrillers (2\%) is the least popular genre among the respondents. The results of the study showed the motives that motivate young people to read contemporary Ukrainian literature. The majority of 159 (53\%) respondents believe that this is one of the crucial means of self-improvement and development, which enables them to assert themselves in all spheres of life.

Key words: sociological survey, literature, book, contemporary Ukrainian literature, information.

Актуальність теми дослідження. Нові потреби та смаки молоді зумовили необхідність грунтовного вивчення іiі інтересів, ролі української книги в ії житті. Отже, поштовхом для проведення дослідження «Українське слово. Що читаєш, молодь?» стало задоволення дозвіллєвих потреб користувачів бібліотеки, отримання соціологічної інформації про роль української книги в житті молоді, виявлення пріоритетів серед сучасних українських письменників, покращення роботи стосовно подальших змін в обслуговуванні молоді.

Дуже важливо не відмовлятися від звичайної друкованої літератури, адже вона сприяє розвитку пам'яті, розвиває мислення та допомагає розслабитися, гарно провівши час на дозвіллі. Відомо, що читачі менше схильні до нервового перенапруження та легше переносять стреси в повсякденному житті. Це вкрай необхідно для сучасної людини, яка звикла до активного щоденного ритму.

Мета дослідження. Виявити рівень популярності сучасної української книги та визначити пріоритети молоді серед сучасних українських письменників задля покращення укомплектованості бібліотечного фонду цією літературою.

Виклад основного матеріалу. Якісна сучасна українська література допомагає осягнути особливості свого часу. Адже саме письменник, як ніхто інший, має сили та сміливість дивитись в очі дійсності. Хороша книга - це порадник і друг для будьякої людини. Вона завжди була найбільшою цінністю людства. Останнім часом ми проголошуємо, що саме через книгу людина залучається до національної культури, адже одним із пріоритетних гуманітарних напрямів діяльності ВОУНБ ім. К. А. Тімірязєва $\epsilon$ популяризація української мови й української книги. Бібліотека має великий досвід задоволення читацьких потреб користувачів. Сьогодення диктує бібліотечним працівникам нові вимоги щодо популяризації української книги як елементу національної самосвідомості. Важливим орієнтиром діяльності ВОУНБ ім. К. А. Тімірязєва є читач нового покоління з його запитами та потребами. Необхідною складовою сучасної просвітницької діяльності книгозбірні стала мотивація молоді до читання українських книг, яке зараз стає актуальним.

Завдання даного дослідження полягали у визначенні рівня поінформованості молоді в галузі сучасної української літератури; визначенні жанрових вподобань молоді; дослідженні мотивів, які спонукають молодь до читання сучасної української літератури; визначенні найбільш комфортного формату читання (електронний чи традиційний). 
Для проведення соціологічного опитування розроблено анкету. Основі етапи анкетування наведено на рисунку 1 [1]. Визначено наступну схему анкетування:

1. Розробка програми анкетування:

- відпрацювання методики збору даних (квітень); (квітень).

- розробка методичного інструментарію

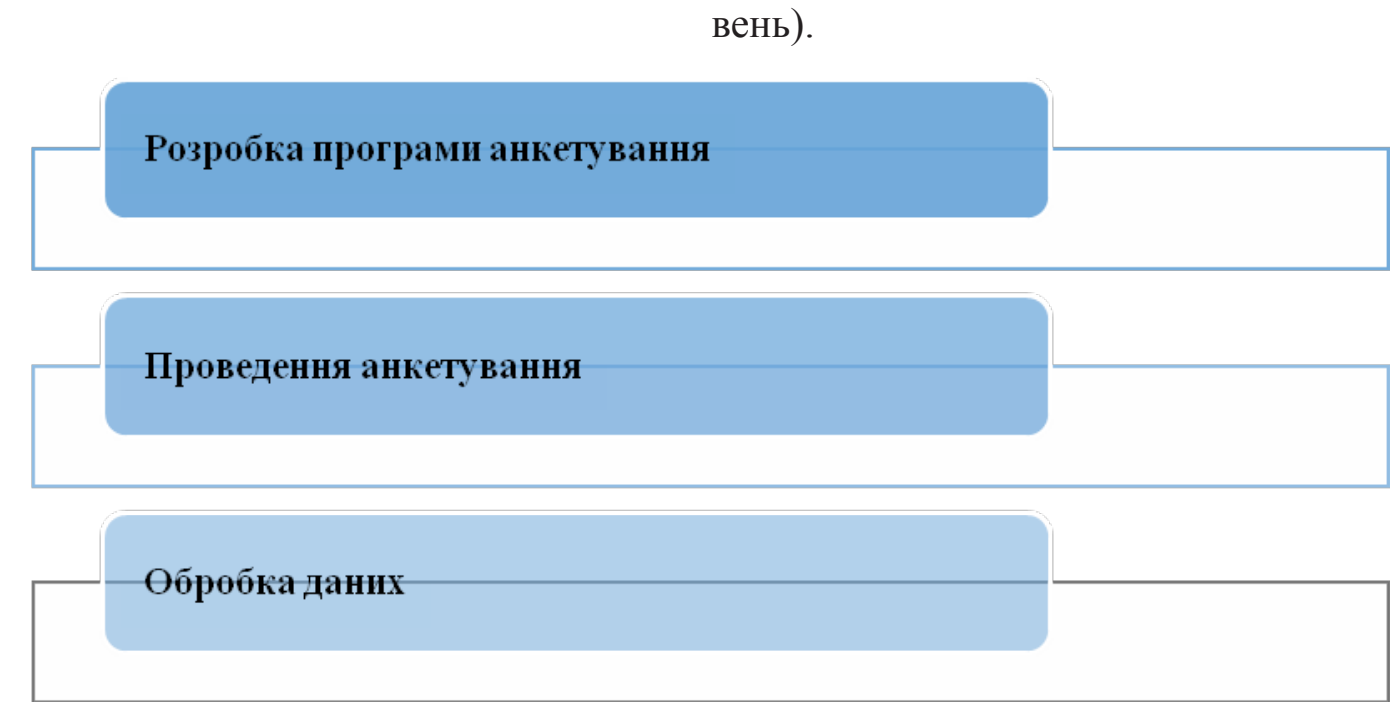

Рисунок 1 - Основні етапи проведення анкетування

Під час опитування використовуються наступні методи анкетування:

- анкетне опитування;

- онлайн-опитування;

- аналіз даних.
2. Проведення анкетування:

- збір даних методом анкетного опитування (друкованого) та онлайн-опитування (з використанням сервісу Google) на головній сторінці веб-сайту Вінницької ОУНБ ім. К. А. Тімірязєва (травень);

- збір узагальнених даних (червень).

3. Обробка даних:

- аналіз та узагальнення результатів (червень). 


\begin{tabular}{|c|c|c|c|}
\hline$\square$ & Курков Андрій & $\square$ & Лис Володимир \\
\hline & Лузіна Лада & $\square$ & Любка Андрій \\
\hline$\square$ & Матіос Марія & $\square$ & Матіяш Дзвінка \\
\hline$\square$ & Медвідь В’яяеслав & $\square$ & Меднікова Марина \\
\hline$\square$ & Подерев'янський Лесь & $\square$ & Положій Євген \\
\hline$\square$ & Прохасько Тарас & $\square$ & Різник Левко \\
\hline$\square$ & Роздобудько Ірен & $\square$ & Сняданко Наталка \\
\hline$\square$ & Сушинський Богдан & $\square$ & Талан Світлана \\
\hline$\square$ & Фіалко Ніна & $\square$ & Татчин Сергій \\
\hline & Шевчук Валерій & $\square$ & Шкляр Василь \\
\hline
\end{tabular}

4. Яка сьогочасна українська книга справила на Вас найбільше враження? Вкажіть назву і автора книги.

5. Який твір сучасного українського письменника викликає бажання прочитати його вдруге?

6. Що надихає Вас звертатися до творів сучасної української літератури?

\begin{tabular}{|c|c|c|}
\hline$\square$ & потреба душі & $\begin{array}{l}\text { прагнення відчути себе обізнаною } \\
\text { людиною }\end{array}$ \\
\hline$\square$ & проведення дозвілля & $\square$ навчання \\
\hline$\square$ & інтерес до нової книги & патріотизм \\
\hline 7 & інше & $\square \quad$ мода на сучасну літературу \\
\hline \multicolumn{3}{|c|}{ 7. Яка література Вас цікавить найбільше? } \\
\hline$\square$ & детективні та кримінальні романи & історичні романи \\
\hline$\square$ & любовні романи & мелодрами \\
\hline$\square$ & містична & наукова \\
\hline$\square$ & пригодницька & психологічна \\
\hline$\square$ & публіцистична & $\square \quad$ трилери \\
\hline$\square$ & фантастика & фентезі \\
\hline$\square$ & філософська & $\square \quad$ мемуари \\
\hline$\square$ & військова тематика & художня проза \\
\hline$\square$ & поезія & інше \\
\hline
\end{tabular}

\section{8. Які твори сучасних українських письменників Ви б порадили прочитати своїм друзям?}

9. Книгу якого сучасного українського автора ви не знайшли у фонді бібліотеки?

10. Надайте коротку інформацію про себе:

\begin{tabular}{|c|c|c|c|}
\hline \multicolumn{4}{|c|}{ Ваша стать: } \\
\hline$\square$ & жіноча & $\square$ & чоловіча \\
\hline \multicolumn{4}{|c|}{ Ваш вік: } \\
\hline$\square$ & $15-17$ & $\square$ & $18-21$ \\
\hline$\square$ & $22-35$ & & \\
\hline \multicolumn{4}{|c|}{ Освіта: } \\
\hline$\square$ & середня & $\square$ & професійно-технічна \\
\hline & базова вища & $\square$ & повна вища \\
\hline
\end{tabular}


Отже, з наведеної таблиці видно, що в анкеті використовувались питання стосовно жанрів літератури, авторів, та інших питань, що допомагають визначити яким книгам надає перевагу українська молодь.

Усім відома фраза: для того, щоб стати розумним,достатньопрочитатидесятькниг,але щоб знайти ті десять, треба прочитати тисячі. 3'ясувати інтерес молоді до українського слова, книги та сучасних українських авторів, нам допомогло соціологічне дослідження «Українське слово. Що читаєш молодь?» [2].

Дослідження здійснювалося методом анкетного опитування (друкованого) та онлайн-опитування (з використанням сервісу Google) на головній сторінці веб-сайту Вінницької ОУНБ ім. К. А. Тімірязєва, згідно 3 розробленою анкетою «Українське слово. Що читаєш молодь?». Серед опитаних 350 користувачівБібліотекикількістьреспондентів жіночої статі становить 209 (60\%), чоловічої 141 (40\%), них 24 (7\%) віком 15- 17 років, 156 (44\%) віком 18-21 рік та 170(49\%) віком 22-35 років.

У дослідженні найактивнішими виявилися респонденти із повною вищою освітою - 178 (51\%), із середньою освітою 119 (34\%), професійно-технічною 27 молодих людей, що становить (8\%) і базовою вищою 26 (7\%). Книга завжди, в усі часи займала особливе місце в інтелектуальному та духовному збагаченні молодого покоління. Сухомлинський В. О. вважав, що «читання не зводиться до вміння читати: 3 цього вміння воно тільки починається. Тому треба домагатися не читання заради читання, а читання як самостійної діяльності молодої людини у світі книжок, з якої починається iї освіта, самовиховання, формування високих художніх смаків, гармонійний розвиток особистості».

На запитання «Що для вас означає читання?» 159 (53\%) респондентів вважають, що це один із важливих засобів самовдосконалення та розвитку, 99 (28\%) вважають читання як можливість відійти від повсякденних проблем і знаходять в ньому душевне заспокоєння, 89 (25\%) із читанням проводять вільний час і лише 3 (1\%) респонденти не читає книг взагалі і не вважає таке заняття за потрібне. Результати відповіді на дане запитання наведено на рисунку 2. 


\section{ЩО ОЗНАЧАС ДЛЯ ВАС ЧИТАННЯ?}

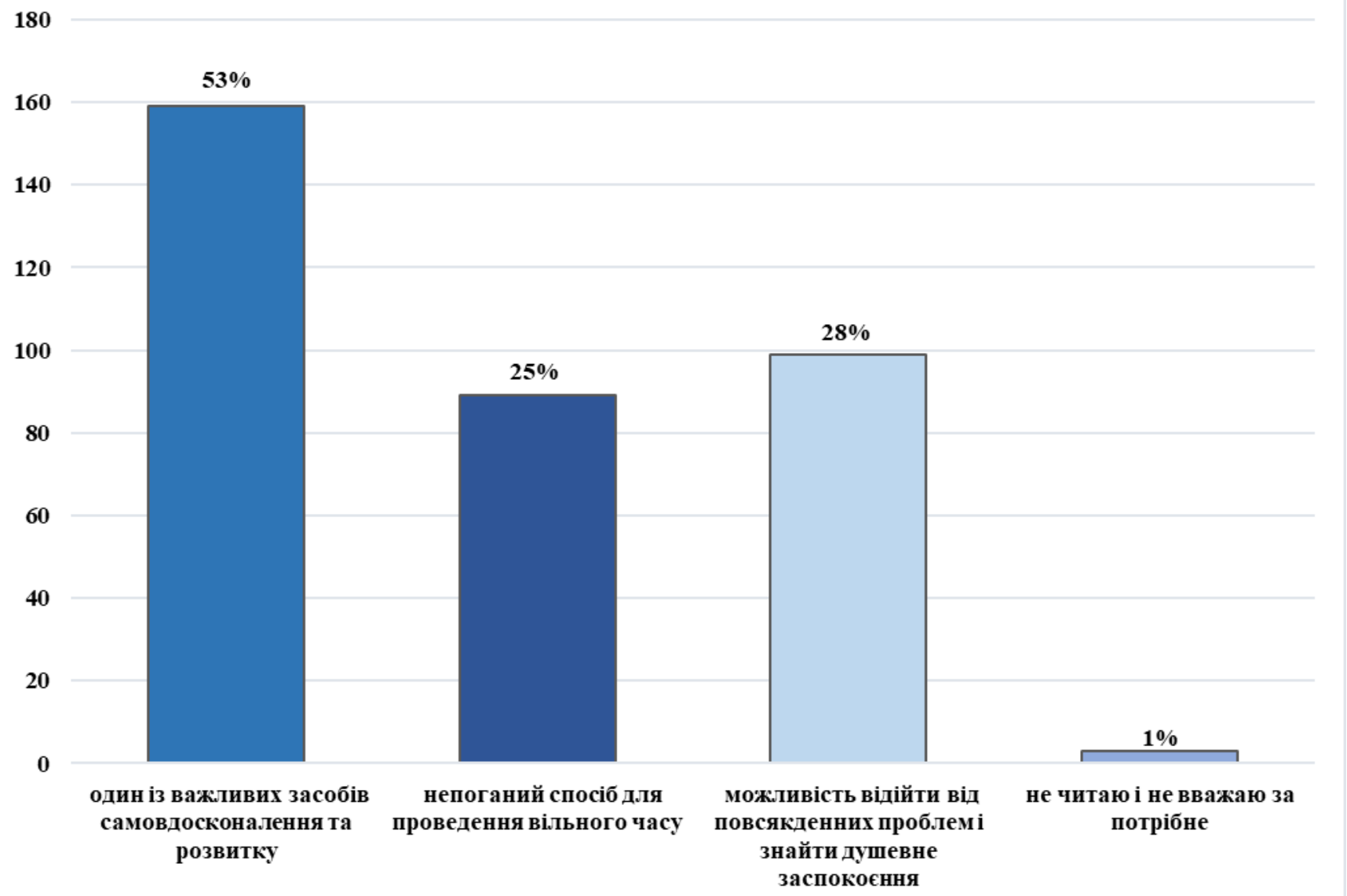

Рисунок 2 - Результати відповіді на запитання « Що для вас означас читання?»

Свій інтерес до читання сучасної української художньої літератури підтвердили 191 (55\%) респондент, і нажаль 159 (41\%) не цікавиться такою літературою. Для сучасної української прози молодь є чи не найголовнішою цільовою аудиторією. Результати наведено на рисунку 3. 


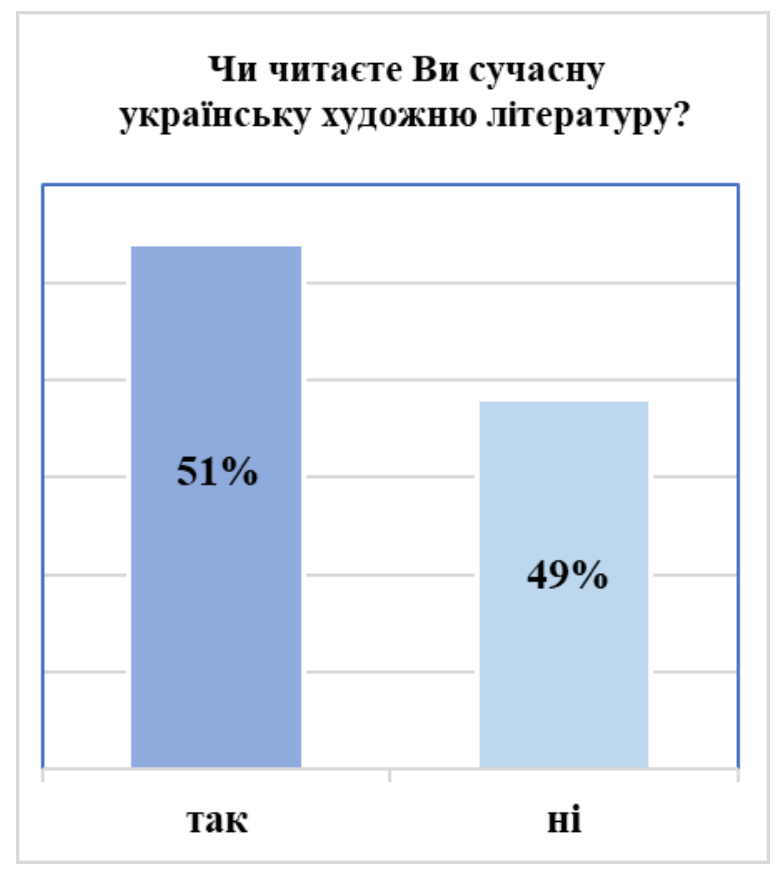

Рисунок 3 - Результати відповіді на запитання «Чи читаєте Ви сучасну українську художню літературу?»

Запитання анкети «3 творчістю якого сучасного українського письменника Ви знайомі?» дало змогу визначити рейтинг найбільш відоміших сучасних українських авторів. Із запропонованих 38 авторів, в десятку потрапили (рис. 4).

Гарна книга може навчити, надихнути, вразити і навіть змінити ставлення читача до певних речей. Улюбленими сьогочасними українськими книгами наших респондентів виявилися [3]:

1. Ліна Костенко «Записки українського сумашедшого» $-12 \%$

2. Дашвар Люко «Село не люди» $-9 \%$

3. Жадан Сергій «Створи щось» $-8 \%$

4. Іздрик Юрій «Ліниві і ніжні» - 7\% $-7 \%$

5. Дереш Любко «Поклоніння ящірки»

6. Кідрук Макс «Не озирайся і мовчи»

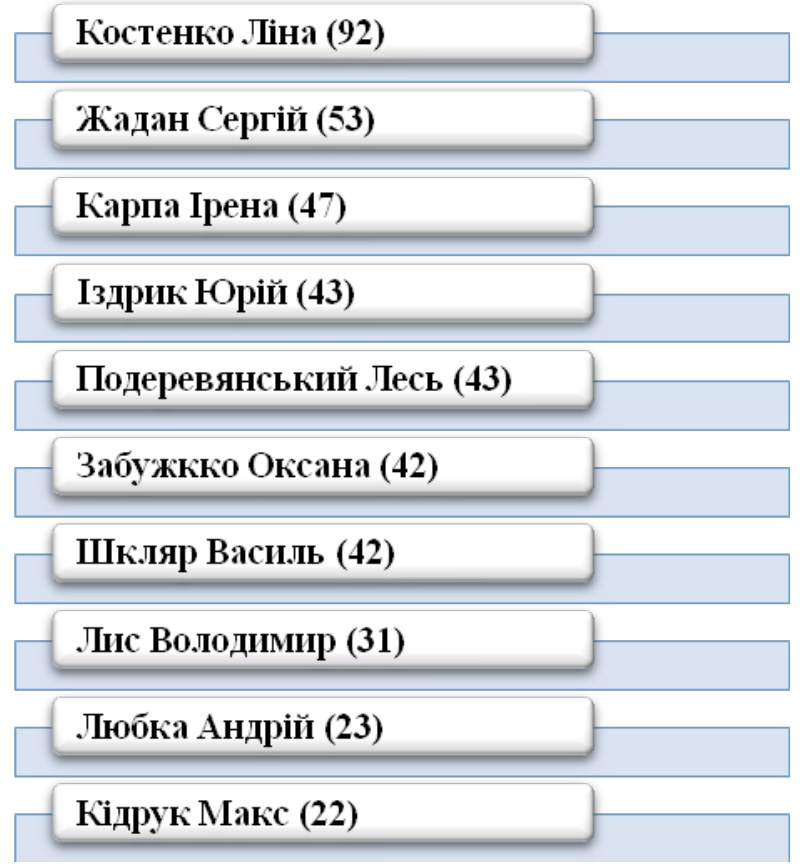

Рисунок 4 - Топ 10 авторів, $з$ творчістю яких знайома молодь

7. Карпа Ірена «3 роси, води і калабані) $-6 \%$

8. Матіос Марія «Солодка Даруся»$5 \%$

9. Доляк Наталка «Гастарбайтерки» $5 \%$

10. Іваничук Роман «Мальви» $-4 \%$

Але $31 \%$ респондентів не надали відповіді.

Повторний перегляд фільму, виставки чи прочитання книги може бути таким же цікавим, як і вперше. Можна не витрачати час на пошук чогось нового та незвичного - i звернутися до того, що вже приносило задоволення. $\mathrm{У} 40 \%$, майже половини опитаних респондентів не виникло бажання ще раз прочитати твір. Так у респондентів виникло бажання прочитати вдруге такі твори (рисунок 5): $-6 \%$ 


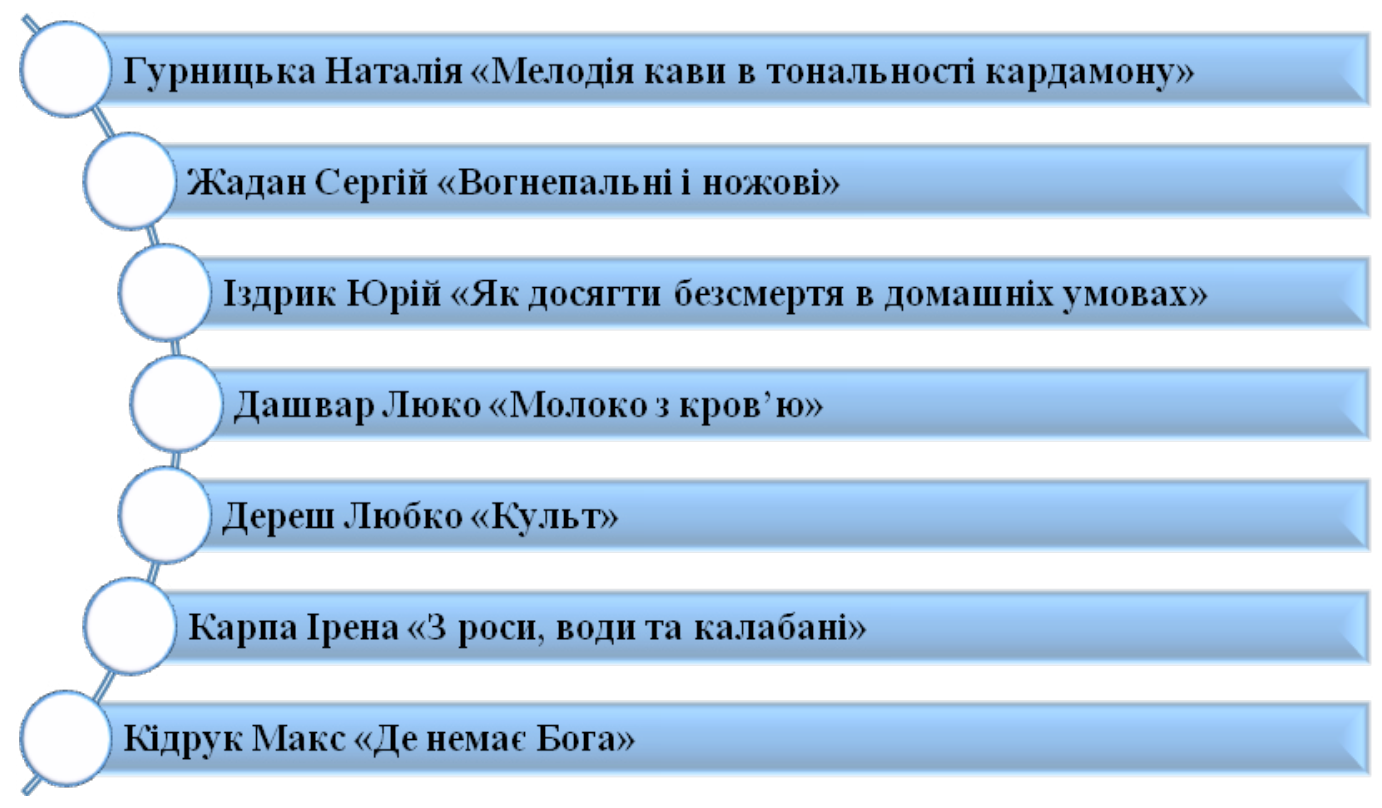

Рисунок 5 - Список книг сучасних авторів, що користуються популярністю

ЯКА ЛІТЕРАТУРА ЦІКАВИТЬ ВАС НАЙБІЛЬШЕ?

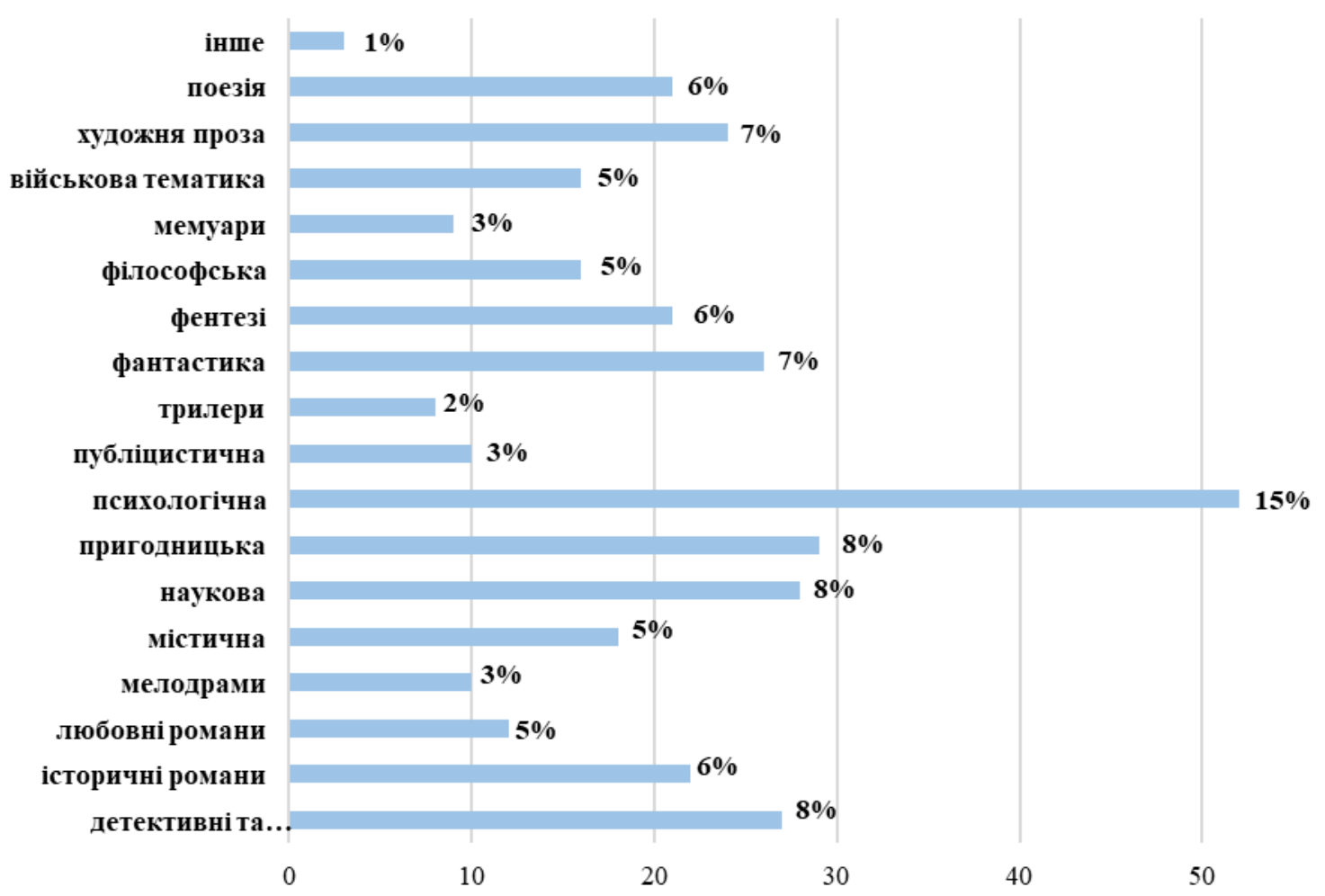


Молодь - дуже уважна та вимоглива аудиторія. Під час дорослішання, життя посилає ій нові виклики, необхідність самовизначення, вона визначає власні інтереси, бажання та розставляє пріоритети. Найпопулярнішою серед молоді є психологічна література - 15\% респондентів цікавляться таким жанром літератури. Пригодницьку, наукову літературу та детективні романи (8\%) вподобала однакова кількість респондентів. Так, за результатами опитування видно, що 7\% респондентів зацікавила фантастика і художня проза, а історичні романи, поезію та фентезі вподобали 6\% респондентів. Містичну, філософську та військову літературу вподобали 5\%, любовними романами, мелодрамами, мемуарами та публіцистикою захоплюється $3 \%$ респондентів. Серед опитаних користувачів $є$ певна кількість таких, які захоплюються читанням трилерів - $2 \%$. Результати даного питання наведено на рисунку 6.

Читання допомагає молодим людям скласти пазл про влаштування світу, дивитись ширше й уважніше, ідентифікувати себе. Це пошук чогось нового і невідомого, можливість вдосконалити свої думки [4]. Безумовно, у кожної людини свої смаки, що ж радять читати друзям молоді люди. Під час дослідження ми з'ясували:

1. Бабкіна Катя «Твори»;

2. Бачинський Андрій «140 децибелів тиші»;

3. Берта Валентина «Твори»;

4. Грін Джон «Провина зірок»;

5. Гурницька Наталія «Мелодія кави в тональності кардамону»;

6. Дашвар Люко «Мати все», «Молоко 3 кров'ю», «На запах м'яса», «Село не люди»;

7. Дереш Любко «Культ»;

8. Доляк Наталка «Загублений між війнами», «Поруч з тобою», «Шикарне життя у Веперталі»;

9. Жадан Сергій «Масопотамія», «ДНК», «Господь симпатизує аутсайдерам»;

10. Забужко Оксана «Музей покинутих секретів», «3 мапи книг і людей», «Сестро, сестро...»;

11. Іздрик Юрій «Острів КРК», «Станіслав і 11 його визволителів», «Воццек \& воццекургія», «Подвійний Леон»;
12. Карпа Ірена «Добрі новини з Аральського моря»;

13. Кідрук Макс «Жорстоке небо»;

14. Корній Дара «Тому що ти є»;

15. Костенко Ліна «Маруся Чурай», «Річка Геракліта»;

16. Любка Андрій «Карбід»;

17. Матіос Марія «Нація», «Майже ніколи не навпаки», «Солодка Даруся»;

18. Нестайко Всеволод «Тореадори з Васюківки»;

19. Подерев’янський Лесь «Твори»;

20. Положій Свген «Іловайськ»;

21. Світлана Талан «Вурдалаки»;

22. Сингаївський Сергій «Дорога на Асмару»;

23. Стус Василь «Твори»;

24. Шкляр Василь «Чорне сонце», «Чорний ворон», «Перший сніг», «Тінь сови», «Кров кажана», «Самотній вовк».

На запитання анкети, книгу якого сучасного українського автора ви не знайшли у фонді бібліотеки $51 \%$ респондентів свої запити задовольнили, 49\% не дали відповіді на запитання.

Отже, результати дослідження допомогли з'ясувати рівень популярності сучасної української книги серед молодих людей, визначити пріоритети молоді серед сучасних українських письменників. Дослідження показало, що вищим є рівень освіти респондентів, то частіше вони читають книжки. Жінки читають друковані книжки частіше, ніж чоловіки. Найпопулярнішим серед молодих читачів жанром є психологічна література (15\%), трилери (2\%) є найменш популярним жанром серед опитаних. Зазвичай найбільшою мірою на вибір книжки для читання впливають рекомендації друзів, тож опитування дало змогу з'ясувати авторів і їх твори які хотіли б порадити прочитати своїм друзям респонденти. Результати дослідження показали мотиви, які спонукають молодь до читання сучасної української літератури. Більшість 159 (53\%) респондентів вважають, що це один із важливих засобів самовдосконалення та розвитку, що дозволяє їм здійснити самоутвердження в усіх сферах життєдіяльності. 
Отримана соціологічна інформація про роль української книги в житті молоді дала змогу виявити пріоритети серед сучасних українських письменників і сприятиме покращенню роботи в обслуговуванні молоді та укомплектованості бібліотечного фонду.

\section{Список використаних джерел}

1. Вербець В. В. Методологія та методика соціологічних досліджень: Навчально-методичний посібник. Друге вид. доп. і перероб. Рівне: РДГУ: Інститут соціальних досліджень, 2006. 167 с.

2. Завадський Ю.Р. Анімаційна поезія як різновид мережевої літератури. Літературознавчі обрії. Праці молодих учених. Випуск 5. Київ: Інститут літератури ім. Т. Г. Шевченка НАН України, 2004. С. $16-21$.

3. Соціологічне дослідження і його види. URL: https://buklib.net/books/28257/

4. Чи «сучасна» сучасна українська література. URL: http://www.leport.com.ua/chi-suchasnasuchasna-ukrayinska-lite/

\section{References}

1. Verbets, V. (2006) Methodology and methodology of sociological research: A manual. Another kind. ext. and recycling. Exactly: RDGU: Institute for Social Research, 167 p. [In Ukrainian].

2. Zavadsky, Yu. (2004). Animated poetry as a kind of network literature. Literary horizons. Works of young scientists. Issue 5. Kiev: Institute of Literature. TG Shevchenko NAS of Ukraine, P. 16-21. [In Ukrainian].

3. Sociological research and its types. (n.d.). Retrieved from: https://buklib.net/books/28257/ [In Ukrainian].

4. Is "contemporary" contemporary Ukrainian literature. (n.d.). Retrieved from: http://www.leport.com. ua/chi-suchasna-suchasna-ukrayinska-lite/ [In Ukrainian]. 